African J. Biol. Sci., 14 (1): 39-51 (2018)

ISSN 1687-4870

e- ISSN 2314-5501 (online)

www.aasd.byethost13.com

E.mail: aasdjournal@yahoo.com

\title{
Utilization from lemongrass and red sorghum bran as natural antioxidant and alternative for fat to improving quality and oxidative stability of beef burger
}

\section{Gehan I. Abd El-Wahab}

Department of Nutrition and Food Science, Faculty of Specific Education, Ain Shams University, Cairo, Egypt

E-mail: gehan-ibrahem@ hotmail.com

\begin{abstract}
This study was carried out to evaluate beef burger prepared from lemongrass and red sorghum bran as a natural antioxidant and alternative for fat at level 10, 20, 30 and 40\% from sheep fat to produce four beef burger formulae. Control beef burger was prepared without any addition. Chemical analyses (moisture, protein, fat, ash, crude fiber and total carbohydrates) were carried out in raw materials (lemongrass and red sorghum bran), beef burger and their formulae during storage period (3 month). Thiobarbituric acid, water holding capacity, plasticity cooking loss, shrinkage, and texture profile analyses (TPA) and total bacterial count were determined in beef burger and their formulae during storage period for 3 months at $-4^{\circ} \mathrm{C}$. Moreover organoleptic characteristics were determined in fresh beef burger and their formulae.

The results showed that the moisture and protein were decreased by increasing storage period as well as total lipids; total ash, crude fiber and total carbohydrates were increased. Plasticity and water holding capacity (WHC) shrinkage and cooking loss were increased during storage period. As the storage period increased, thiobarbituric acid (TBA) values increased for all beef burger and their formulae.

During the storage period, the control beef burger showed the highest of total bacterial count, while, the formulae were observed the lowest one when lemongrass and red sorghum bran increased where they are rich in their natural antioxidant which protective the sheep fat in the formulae from oxidative. The organoleptic evaluations showed that the beef burger formula replacement sheep fat at level 10,20 and 30\%, respectively had higher acceptability (45.0, 40.0 and 37.5) and nearly control beef burger (45.0). Whereas, the beef burger formula replacement fat at level $40 \%$ had the lowest acceptability (30.0).

It can be recommended that the lemongrass and red sorghum bran can play an important role as antioxidant, reduce oxidative sheep fat and antibacterial agents in refrigerated beef burger and their formulae.
\end{abstract}

Key words: Lemongrass, red sorghum hull, beef burger, antioxidant.

\section{INTRODUCTION}

Meat and its products are highly perishable and can spoil very easily if they are not store properly. Once they spoiled, they become unhealthy to eat due to microbial growth and chemical changes by enzymes (Judge et al., 1990). In general, lipid oxidation is considered one of the most important causes of quality deterioration in meat and it produces the off flavors and odors, in addition to the increase of the drip losses, loss of pigment and as a result decrease the consumer acceptability (Morrissey et al., 1994). This deterioration is mainly due to the contamination of meat and its products through production, handling and consumption (Altabari, 2009). In addition to the cross contamination during processing, poor personal hygiene and inappropriate holding temperature also contribute to the contamination of ready food to eat (Mensah et al., 2002). 


\section{Gehan I. Abd El-Wahab}

Cymbopogon citratus (lemon grass) is an aromatic perennial tall grass with rhizomes and densely tufted fibrous root. It has short underground stem with ringed segments, coarse green slightly leathery leaves in dense clusters. The plant is a native herb from India and is cultivated in other tropical and subtropical countries (Mehraban et al., 2005; Figueirinha et al., 2008). It is used as traditional folk medicine in the treatment of nervous gastrointestinal disturbances fever, hypertension (Melo et al., 2001; Abubakar et al., 2008). Recent attention has been paid to extracts of biologically active components isolated from plant species. The medicinal value of plants lies in some chemical substances that produce a definite physiological action in human body. The most important of these bioactive constituents are alkaloids, tannins, flavonoids, phlobotannins, saponins and cardiac glycoside (Edeoga et al., 2005; Abubakar et al., 2008).

\section{Lemongrass}

(Cymbopogon

citrates) is a rich source of citric, which is used in perfumery and pharmaceutical industries, and bioactive compounds (flavonoids and vitamin C). The natural flavonoids are also attracting more and more attention not only due to their antioxidant properties, but as anticarcinogenic and anti-inflammatory agents because of their lipid anti-peroxidation effects (Martin et al., 2002).

Citrus fruits are an important source of bioactive compounds (flavonoids and vitamin $\mathrm{C}$ ). Flavonoids present in citrus possess antioxidant activity owing to their free radical scavenging ability (Anagnostopoulou et al., 2006). The flavonoids are potent antioxidants agents and protect the cells by scavenging and inhibiting the production and initiation of free radicals, superoxide anions and lipid peroxy radicals. The antioxidant capacity of meat is very low and this can be increased by adding flavonoids in meat during processing in the form of plant parts rich in flavonoids such as seeds, fruit skin or peel without compromising the sensory attributes of meat and meat products (Kumar et al., 2013)

Sorghum (Sorghum bicolor L.) (Moench) contains phenolic compounds in the form of phenolic acids, flavonoids and condensed tannins (Waniska, 2000), which have been shown to have antioxidant activity (Awika et al., 2003b and 2004). These phenolic compounds, which are concentrated in the outer layers of the sorghum grain (pericarp and testa) (Beta $e t$ al., 2000), possess structural features favorable for radical scavenging and/or metal chelating, which would enable them to be effective antioxidants. The pericarp and testa are often removed and disposed of as bran during utilization of sorghum flour. A potential therefore exists to use sorghum bran as a cheap source of natural antioxidants to prevent the development of oxidative rancidity in edible oils and other lipid food systems. Several raw data on levels of phenolic content and antioxidant activities in sorghum grains are available (Dykes and Rooney, 2007).

Sorghum bran contains high levels of phenols, policosanols and sterols. The phenolic compounds serve as defenses for the sorghum against pests and diseases (Awika and Rooney, 2004). Although various phytochemicals in sorghum are available depending on species, phenolic acids and flavonoids are the most abundant. These phenolic acids and flavonoids are considered to be the major compounds acting as antioxidants. Tannins are polymeric compounds formed from flavonoids during the break down of tissues (Kumar and Sinha, 2004). Tannins are divided into two groups: condensed and hydrolysable tannins. Condensed tannins are large polymers present in some sorghum. They form an insoluble complex with proteins and carbohydrates (Awika et al., 2003a).

Some anthocyanins in sorghum may affect meat color by the presence of a hydroxyl group at the C-3 position, although 3-deoxyanthocyanidins are the 


\section{Utilization from lemongrass and red sorghum bran as natural antioxidant and alternative for fat to improving quality and oxidative stability of beef burger}

most common in sorghum. A hydroxyl group at the $\mathrm{C}-3$ position of anthocyanin shifts the color from yellow-orange to red (Ahmed et al., 2004). The complex reactions of $\mathrm{pH}$ and sorghum bran have been shown to increase color stability and provide darker, but less red and yellow, ground beef color (Jenschke, 2004; Hemphill, 2006).

The aim of this study is to evaluate the effects of added lemongrass and red sorghum bran as natural antioxidant and replacement fat in beef burger on its quality attributes and estimate the antimicrobial effect during storage period for 3 months. Chemical analysis, physical characteristics, microbiological analysis and sensory evaluation were determined in beef burger formulae contained different concentrations of lemongrass and red sorghum bran.

\section{MATERIALS AND METHODS Materials:}

Imported Brazil beef (frozen) and fat tissues were purchased from the private sector shop in the local market at Giza, Egypt. Lemongrass (Cymbopogon citrates) leaves was obtained from the Horticultural Research Institute, Agricultural Research Center, Giza Egypt. Red sorghum (Sorghum bicolor L.) cultivar Assuit 14 was purchased from Filed Crops Research Institute, Agricultural Research Center, Giza Egypt. Sorghum grains were finely ground and passed through a Willy mill 40 mesh sieve to separate sorghum bran.

\section{Methods:}

\section{Extraction of the phytochemical from} lemongrass and red sorghum bran.

The phenolic acids, flavonoids compounds and anthocyanin content from lemongrass and red sorghum bran were extracted by the method followed by Joseph et al. (2004). Two solvents, methanol $70 \%$ and acidified methanol $(1 \%$ $\mathrm{HCl})$ were used for extraction procedure.
The different extracts were stored at $-20^{\circ} \mathrm{C}$ in the dark until further biochemical analysis.

Determination of the phytochemical composition in lemongrass and red sorghum bran extracts.

Total phenolic contents samples were determined by the Folin-Ciocalteu's method (Meda et al., 2005) in two solvents. The absorbance of the reaction mixture was measured at $750 \mathrm{~nm}$ against a deionized water blank using a spectrophotometer. The data obtained from lemongrass and red sorghum bran were expressed as milligram of gallic acid equivalents (GAEs)/g powder and converted to milligram gallic acid equivalents (GAEs)/ $\mathrm{g}$.

The total flavonoid content was quantified by using aluminum chloride colorimetric method described by Chang et al. (2002) in two solvents. The data obtained from lemongrass and red sorghum hull were expressed as milligram of quercetin equivalents $(\mathrm{QE}) / \mathrm{g}$ powder. Finally, the data were converted to milligram quercetin equivalents $(\mathrm{QE}) / \mathrm{g}$.

The total amount of anthocyanin content was determined using two solvents. A spectrophotometer was used for the spectral measurements at $750 \mathrm{~nm}$ (Fuleki and Francis, 1968). The data were converted to milligram cyanidin 3glucoside equivalents /g.

\section{Preparation of beef burger formulae:}

Beef burger control and added lemongrass and red sorghum bran as natural antioxidant and alternative for fat at level 10, 20, 30 and 40\% from sheep fat then it was mixed with the other ingredients to prepare the final mixture to manufacture four beef burger formulae. The ingredients of the control and tested formulae are shown in Table (1).

Minced beef meat and other ingredients were homogenized manually, after that the batch of about $1 \mathrm{~kg}$ was 


\section{Gehan I. Abd El-Wahab}

manually, cut and rounded in about $50 \mathrm{~g}$ each pieces and finally formed using Hollymatic machine (Model 2004). Beef burger and their formulae were kept in plastic bags and stored at $-4^{\circ} \mathrm{C}$ for three months.

Table (1): The ingredients of control beef burger and other tested formulae $\mathrm{g} / \mathbf{1 0 0 g}$.

\begin{tabular}{|c|c|c|c|c|c|}
\hline Recipes & Control & Formula 1 & Formula 2 & Formula 3 & Formula 4 \\
\hline Beef meat & 70.0 & 70.0 & 70.0 & 70.0 & 70.0 \\
\hline Sheep fat & 10.0 & 9.0 & 8.0 & 7.0 & 6.0 \\
\hline Red sorghum bran & ---- & 0.5 & 1.0 & 1.5 & 2.0 \\
\hline Lemongrass & ----- & 0.5 & 1.0 & 1.5 & 2.0 \\
\hline Onion & 8.0 & 8.0 & 8.0 & 8.0 & 8.0 \\
\hline Salt & 2.0 & 2.0 & 2.0 & 2.0 & 2.0 \\
\hline Rusk & 7.0 & 7.0 & 7.0 & 7.0 & 7.0 \\
\hline Spices & 3.0 & 3.0 & 3.0 & 3.0 & 3.0 \\
\hline
\end{tabular}

\section{Chemical analyses of beef burger formulae:}

Chemical analyses (moisture, protein, fat, crude fibers and ash) were determined in raw materials (lemongrass and red sorghum bran), beef burger formulae during the storage period according to AOAC (2005) methods. Total carbohydrates were calculated by the difference.

\section{Physical properties of beef burger formulae:}

Water Holding Capacity (WHC) and plasticity in the beef burger formulae were measured during storage period according to the filter press method of Soloviev (1966). Shrinkage (\%) of the tested samples was determined after frying at $180^{\circ} \mathrm{C}$ as equation [(Fresh sample diameter) - (Fried sample diameter) / (Fresh sample diameter) $\times 100]$. The cooking loss of beef burger and their formulae during storage period was determined as the method described by AMSA (1995). Thiobarbituric acid (TBA) was determined in beef burger formulae during storage period according to the method described by Schmedes and Holmer (1989).

Texture profile analyses of beef burger formulae:

The texture profile analyses (TPA) indices of beef burger formulae were determined using a texture analyzer (Cometech, B type, Taiwan). The conditions of texture analyzer were provided with software, $35 \mathrm{~mm}$ diameter compression disc was used. Two cycles were applied at a constant crosshead velocity of $1 \mathrm{~mm} / \mathrm{s}$, to $30 \%$ of sample depth then returned. From the resulting force-time curve the values for texture attributes i.e. firmness, gumminess, chewiness, cohesiveness, springiness and resilieness were calculated from TPA graphic according to Bourne (2003).

\section{Microbiological analysis of beef burger formulae:}

Total bacterial count (TBC) of beef burger and their formulae, during storage period was determined according to American Public Health Association (1992).

\section{Organoleptic evaluation of beef burger formulae:}

Organoleptic evaluation of fresh beef burger formulae were determined by the method described with Morr (1970).

\section{Statistical analysis}

The obtained data were exposed to analysis of variance. Duncan's multiple range tests at $(P \leq 0.05)$ level was used to compare between means. The analysis was carried out using the PRO ANOVA 
Utilization from lemongrass and red sorghum bran as natural antioxidant and alternative for fat to improving quality and oxidative stability of beef burger

procedure of Statistical Analysis System (SAS, 2004).

\section{RESULTS AND DISCIUSSION}

Phytochemical composition in lemongrass and red sorghum bran extracts

Total phenolic acids, flavonoid compounds and anthocyanin content were determined in lemon grass and red sorghum bran using two solvents, methanol $70 \%$ and acidified methanol $(1 \%$ $\mathrm{HCl}$ ) and the results are reported in Table (2). From the resultant it could be noticed that the lemongrass had contained the highest amounts from total phenolics and flavonoid compounds in the extracts from methanol $70 \%$ and acidified methanol. Whereas red sorghum bran was the highest amounted in anthocyanin content using two solvents, methanol $70 \%$ and acidified methanol and the results are 111.0 and
$146.0 \mathrm{mg}$ cyaniding- 3 - glucoside equivalent/g.

Asaolu et al. (2009) analyzed the phytochemical constituents of the leaves of Cymbopogon citrates using and the results showed that the lemongrass contains alkaloids, saponins, tannins, anthrocyanins, steroids, phenols and flavonoids. Each or these phytochemical is known for various protective and therapeutic effects.

Awika et al. (2005) reported that the highest concentrations of phenols were present in sorghum hull. However, since acidified methanol was used as preservers better the extracted anthocyanins in their original form; it can be the solvent of choice for quantification and analysis of anthocyanins. The pigmented sorghum varieties are a superior source of these beneficial compounds.

Table (2): Antioxidants in lemongrass and red sorghum bran extracts.

\begin{tabular}{|c|c|c|c|c|c|c|}
\hline \multirow{2}{*}{ Solvents } & \multicolumn{3}{|c|}{ Lemongrass } & \multicolumn{3}{c|}{ Red sorghum bran } \\
\cline { 2 - 7 } & TP & FC & AC & TP & FC & AC \\
\hline Methanol 70\% & 4.23 & 8.64. & 0.63 & 0.57 & 1.99 & 111.0 \\
\hline $\begin{array}{c}\text { Acidified } \\
\text { methanol }\end{array}$ & 7.56 & 11.45 & 0.92 & 0.98 & 4.75 & 146.0 \\
\hline
\end{tabular}

TPA: Total phenolics mg gallic acid equivalent/g.

TF: Flavonoids compounds mg queractin equivalent/g.

AC: Anthocyanin content mg cyaniding-3-glucoside equivalent/g.

\section{Chemical compositions of beef burger formulae during storage period \\ Chemical constituents were} determined in beef burger formulae made from lemon grass and red sorghum bran as alternative fat and natural antioxidant during storage period (three months) and the results are reported in Table (3). From the resultant it could be noticed that the lemon grass was higher in protein, crude fat, ash content and crude fiber $(15.5,10.0$, 9.17 and $16.5 \%$ on wet weight) than red sorghum bran was 11.6, 9.3, 5.46 and $10.14 \%$ on wet weight. The increases in crude fat in red sorghum bran may be caused the decortications process removes the outer layers of sorghum, mainly pericarp, but it includes some germ tissue and residual starch from the endosperm.

The results from protein in beef burger formulae showed that no changed in different formulae than control beef burger and it was slightly decreased by increasing lemon grass and red sorghum bran as alternative fat during storage period. These results showed that the lemon grass and red sorghum bran had contained 15.50 and $11.60 \%$ on wet weight protein when substituted with sheep fat the protein in the formulae was slightly increased. Whereas, the total lipid during three month was decreased in the 


\section{Gehan I. Abd El-Wahab}

all formulae by increasing lemon grass and red sorghum bran as alternative fat at zero time were $10.29,9.33,8.14$ and $7.10 \%$, respectively on wet weight basis compared with control beef burgher $10.30 \%$ and it was increased gradually by increasing storage period. These results indicated that the gradually lower total lipid in the all formulae at zero time during storage period may be caused the lemon grass and red sorghum bran was alternative the sheep fat in the formulae at different levels. Moreover, the ash and crude fiber were increased in the formulae at different levels and during storage period, this may be the lemon grass and red sorghum bran has been contained rich in crude fiber. The changes in total carbohydrates of beef burger and their formulae may be related to some other changes in different chemical constituents.

Table (3): Chemical compositions of beef burger formulae during storage period (three months) on wet weight basis.

\begin{tabular}{|c|c|c|c|c|c|c|c|}
\hline Formulae & $\begin{array}{c}\begin{array}{c}\text { Storage } \\
\text { period }\end{array} \\
\end{array}$ & Moisture & Protein & Lipids & Ash & $\begin{array}{l}\text { Crude } \\
\text { fibers }\end{array}$ & T.C. \\
\hline Lemongrass & - & 11.33 & 15.50 & 12.0 & 9.17 & 16.50 & 35.50 \\
\hline Red sorghum bran & - & 10.25 & 11.60 & 9.30 & 5.46 & 10.14 & 53.25 \\
\hline \multirow[t]{4}{*}{ Control } & 0 & 61.23 & 15.93 & 10.30 & 1.20 & 0.34 & 11.00 \\
\hline & 1 & 60.50 & 15.75 & 10.50 & 1.27 & 0.52 & 11.46 \\
\hline & 2 & 59.60 & 15.60 & 10.84 & 1.43 & 0.71 & 11.82 \\
\hline & 3 & 58.70 & 15.40 & 11.28 & 1.59 & 0.91 & 12.12 \\
\hline \multirow[t]{4}{*}{ Formulae 1} & 0 & 60.57 & 15.93 & 10.29 & 1.29 & 0.49 & 11.43 \\
\hline & 1 & 60.13 & 15.75 & 10.43 & 1.31 & 0.67 & 11.71 \\
\hline & 2 & 59.24 & 15.52 & 10.77 & 1.45 & 0.85 & 12.17 \\
\hline & 3 & 58.32 & 15.32 & 11.12 & 1.64 & 1.11 & 12.58 \\
\hline \multirow[t]{4}{*}{ Formulae 2} & 0 & 60.71 & 15.92 & 9.33 & 1.51 & 0.85 & 11.68 \\
\hline & 1 & 60.00 & 15.72 & 9.73 & 1.67 & 0.98 & 11.90 \\
\hline & 2 & 59.27 & 15.54 & 9.92 & 1.81 & 1.11 & 12.35 \\
\hline & 3 & 58.35 & 15.30 & 10.20 & 1.95 & 1.32 & 12.88 \\
\hline \multirow[t]{4}{*}{ Formulae 3} & 0 & 60.65 & 15.90 & 8.14 & 2.03 & 1.17 & 12.11 \\
\hline & 1 & 60.12 & 15.71 & 8.47 & 2.21 & 1.24 & 12.25 \\
\hline & 2 & 59.22 & 15.58 & 8.85 & 2.42 & 1.43 & 12.50 \\
\hline & 3 & 58.33 & 15.31 & 9.15 & 2.59 & 1.65 & 12.97 \\
\hline \multirow[t]{4}{*}{ Formulae 4} & 0 & 61.10 & 15.90 & 7.10 & 2.15 & 1.35 & 12.40 \\
\hline & 1 & 60.50 & 15.60 & 7.42 & 2.38 & 1.51 & 12.59 \\
\hline & 2 & 60.12 & 15.40 & 7.55 & 2.44 & 1.63 & 12.86 \\
\hline & 3 & 59.43 & 15.26 & 7.84 & 2.61 & 1.83 & 13.05 \\
\hline
\end{tabular}

a control sample and their formulae showed that the moisture and protein slightly decreased by increasing storage period, while crude fibers and total lipids increased by increasing the storage period. The decreases of total protein in beef burger and their formulae may be due to the activation effect of microbial load which may cause protein hydrolysis with the appearances of alkyl groups (Yassin, 2003). In our results the protein in different beef burger formulae were slightly decreased may be caused the lemon grass and red sorghum bran as natural antioxidant had protect the protein and lipid. Moreover, the gradual percentage increases in ash, crude fibers and total lipids for beef burger and their formulae during storage period may be caused by the lemongrass and thyme containing increased high amount from ash, crude fibers and total lipids. 

alternative for fat to improving quality and oxidative stability of beef burger

\section{Physical characteristics of beef burger formulae during storage period}

Water holding capacity (WHC) is one of the most important properties, including the eating quality, tenderness, juiciness, thawing drip and cooking loss of meat and meat products. Water holding capacity (WHC), plasticity, shrinkage and cooking loss were determined in beef burger and their formulae during storage period, and the results are reported in Table (4). The results data showed that the plasticity in beef burger as control and their formulae were evident increased at zero time $(2.50,2.62,2.64,2.68$ and 2.71 $\mathrm{cm}^{2} / 0.3 \mathrm{~g}$, respectively), and it was increasing by substituted fat with lemon grass and red sorghum bran, moreover the formulae were gradually decreased during storage. The results from water holding capacity (WHC) showed that the beef burger as control and their formulae were increased by increasing lemongrass plus red sorghum bran as alternative fat and it was increasing during storage period. This may be due to gradually increase in WHC during storage period, lemon grass and red sorghum bran had contained rich amounts from crude fiber and ash content.

The data presented in Table (4) show that the shrinkage and cooking loss in beef burger formulae were decreased during storage period than control beef burger. $t$ This may be attributed to lemon grass and red sorghum bran had contained rich amounts of natural antioxidant which delay the microbial population and bacterial growth and it was antimicrobial agents. Moreover, the incremental pattern in TBA values for all the stored formulae with advancing the chilling storage time may be due to the auto-oxidation of meat lipids, bacteriological and/or oxidative rancidity. TBA value is routinely used as an index of lipid oxidation in meat products in store (Raharjo and Sofos, 1993).

Table (4): Physical characteristics of beef burger formulae during storage period (three months)

\begin{tabular}{|c|c|c|c|c|c|c|}
\hline Formulae & $\begin{array}{l}\text { Storage period } \\
\text { per month }\end{array}$ & $\begin{array}{l}\text { Plasticity } \\
\left(\mathrm{cm}^{2} / 0.3 \mathrm{~g}\right)\end{array}$ & $\begin{array}{c}\text { WHC } \\
\left(\mathrm{cm}^{2} / 0.3 \mathrm{~g}\right)\end{array}$ & $\begin{array}{c}\text { Shrinkage } \\
\%\end{array}$ & $\begin{array}{c}\text { Cooking loss } \\
\%\end{array}$ & $\begin{array}{r}\text { TBA } \\
\text { mg \% }\end{array}$ \\
\hline \multirow[t]{4}{*}{ Control } & 0 & 2.50 & 3.15 & 15.50 & 22.82 & 0.47 \\
\hline & 1 & 2.30 & 3.31 & 16.20 & 23.24 & 0.54 \\
\hline & 2 & 2.03 & 4.47 & 17.50 & 25.91 & 0.69 \\
\hline & 3 & 1.60 & 4.95 & 18.50 & 28.88 & 0.82 \\
\hline \multirow[t]{4}{*}{ Formulae 1} & 0 & 2.62 & 3.21 & 15.43 & 21.32 & 0.36 \\
\hline & 1 & 2.35 & 3.44 & 15.90 & 23.02 & 0.43 \\
\hline & 2 & 2.12 & 4.60 & 16.10 & 24.60 & 0.58 \\
\hline & 3 & 1.70 & 5.25 & 16.50 & 26.30 & 0.71 \\
\hline \multirow[t]{4}{*}{ Formulae 2} & 0 & 2.64 & 3.27 & 15.45 & 21.30 & 0.35 \\
\hline & 1 & 2.39 & 3.50 & 15.92 & 23.22 & 0.40 \\
\hline & 2 & 2.11 & 4.76 & 16.15 & 24.85 & 0.55 \\
\hline & 3 & 1.86 & 5.40 & 16.55 & 26.45 & 0.68 \\
\hline \multirow[t]{4}{*}{ Formulae 3} & 0 & 2.63 & 3.30 & 15.46 & 21.31 & 0.34 \\
\hline & 1 & 2.37 & 3.80 & 15.95 & 23.19 & 0.38 \\
\hline & 2 & 2.10 & 4.55 & 16.20 & 24.70 & 0.52 \\
\hline & 3 & 1.90 & 5.65 & 16.60 & 26.49 & 0.66 \\
\hline \multirow[t]{4}{*}{ Formulae 4} & 0 & 2.71 & 3.40 & 15.48 & 21.34 & 0.33 \\
\hline & 1 & 2.38 & 3.85 & 16.15 & 23.36 & 0.36 \\
\hline & 2 & 2.21 & 5.15 & 17.45 & 25.14 & 0.48 \\
\hline & 3 & 2.00 & 5.85 & 18.40 & 27.80 & 0.64 \\
\hline
\end{tabular}

WHC Water holding capacity. 


\section{Gehan I. Abd El-Wahab}

\section{Organoleptic properties of beef burger formulae:}

Sensory evaluation is used to measure human responses to foods with different techniques to get important and useful information (Lawless and Heymann, 2010). Sensory evaluation is defined as a scientific method for analyze, evoke, measure and interpret responses to products under controlled conditions with the help of sight, smell, touch, taste and hearing. The tested samples are often labeled with random numbers and served in different orders for counterbalance of other judgments than the sensory experience.

Table (5) showed that the organoleptic properties of beef burger formulae made from lemon grass and red sorghum bran as alternative fat and natural antioxidant. From Table (5), it could be noticed that the beef burger formula replacement fat with at level 10, 20 and $30 \%$, respectively were acceptability (45.0,40.0 and 37.5) and nearly control beef burger (45.0). Whereas, the beef burger formula replacement fat at level $40 \%$ was the lowest acceptability (30.0). These results showed that the replacement fat with lemon grass and red sorghum bran were acceptability till $30 \%$ caused lemon grass and red sorghum bran is a good source for many nutrients such as protein, fiber and natural antioxidant.

Bran can be incorporated in food as replacement of flour, fat or sugar as enhancers of water and oil retention and emulsion improver but the amount is limited due to undesirable changes like color and texture (Elleuch et al., 2011).

Table (5): Organoleptic properties of beef burger formulae.

\begin{tabular}{|c|c|c|c|c|c|c|}
\hline Formulae & Aroma (10) & Taste (10) & Color (10) & Texture (10) & Flavor (10) & $\begin{array}{c}\text { Over all } \\
\text { acceptability }\end{array}$ \\
\hline Control & $9.00^{\mathrm{a}} \pm 0.12^{\mathrm{a}}$ & $9.00^{\mathrm{a}} \pm 0.10$ & $9.00^{\mathrm{a}} \pm 0.11$ & $9.00^{\mathrm{a}} \pm 0.11$ & $9.00^{\mathrm{a}} \pm 0.12$ & 45.0 \\
\hline Formula 1 & $9.00^{\mathrm{a}} \pm 0.14$ & $9.00^{\mathrm{a}} \pm 0.12$ & $9.00^{\mathrm{a}} \pm 0.12$ & $9.00^{\mathrm{a}} \pm 0.12$ & $9.00^{\mathrm{a}} \pm 0.12$ & 45.0 \\
\hline Formula 2 & $8.00^{\mathrm{ab}} \pm 0.15$ & $8.00^{\mathrm{ab}} \pm 0.16$ & $8.00^{\mathrm{ab}} \pm 0.15$ & $8.00^{\mathrm{ab}} \pm 0.14$ & $8.00^{\mathrm{ab}} \pm 0.14$ & 40.0 \\
\hline Formula 3 & $7.50^{\mathrm{b}} \pm 0.12$ & $7.50^{\mathrm{b}} \pm 0.13$ & $7.50^{\mathrm{b}} \pm 0.13$ & $7.50^{\mathrm{b}} \pm 0.14$ & $7.50^{\mathrm{b}} \pm 0.14$ & 37.5 \\
\hline Formula 4 & $6.00^{\mathrm{c}} \pm 0.13$ & $6.00^{\mathrm{c}} \pm 0.14$ & $6.00^{\mathrm{c}} \pm 0.11$ & $6.00^{\mathrm{c}} \pm 0.10$ & $6.00^{\mathrm{c}} \pm 0.12$ & 30.0 \\
\hline
\end{tabular}

\section{Texture profile analyses of beef burger formulae}

Table (6) showed that the results of texture properties analysis after replacing fat with lemon grass and red sorghum bran at different level in beef burger formulae. Firmness was between 4.29 and 11.86; cohesiveness between 0.51 and 2.15 , gumminess between 2.12 to 11.68 , chewiness between 1.51 and 3.05, springiness between from 0.60 to 0.75 and finely, resilience was between from 0.45 to 0.59. The increasing addition of lemongrass and red sorghum bran were influenced the texture of beef burger formulae may be caused lemon grass and red sorghum bran were high contained amounts of crude fiber. Chambers and Bowers (1993) suggested that of the characteristics of texture, hardness is the most significant factor in influencing consumer preference towards meat product.

Low fat frankfurter prepared by adding seaweed improved water and fat binding property, and it also increased hardness and chewiness quality with enriched n-3 PUFA, but less acceptable flavor due to the presence of seaweed (Lopez et al., 2009). 
Utilization from lemongrass and red sorghum bran as natural antioxidant and alternative for fat to improving quality and oxidative stability of beef burger

Table (6): Texture profile analyses of beef burger formulae.

\begin{tabular}{|c|c|c|c|c|c|c|}
\hline Formulae & Firmness & Cohesiveness & Gumminess & Chewiness & Springiness & Resilience \\
\hline Control & 4.29 & 0.51 & 2.12 & 1.51 & 0.60 & 0.45 \\
\hline Formula1 & 5.32 & 0.79 & 5.24 & 1.86 & 0.64 & 0.47 \\
\hline Formula2 & 7.24 & 1.25 & 8.36 & 2.11 & 0.67 & 0.49 \\
\hline Formula3 & 9.61 & 1.73 & 10.54 & 2.34 & 0.69 & 0.52 \\
\hline Formula4 & 11.13 & 1.82 & 11.24 & 2.82 & 0.71 & 0.55 \\
\hline
\end{tabular}

Total bacteria count of beef burger formulae during storage period.

It was obvious from the results in Table (7) that the total bacterial count of beef burger and their formulae during storage period. The control beef burger showed values of total bacterial counts were 99, 141, 213 and $305 \times 10^{3} \mathrm{CFU}$, respectively. While, beef burger formulae total bacterial counts amounted to 94, 102, 120 and $150 \times 10^{3} \mathrm{CFU}$, in formula 1 and in formula 2 was $97,109,127$ and $167 \times 10^{3}$
CFU, respectively, whereas, formula 3 showed that the bacteria count had contained 96, 108, 125 and $161 \times 10^{3} \mathrm{CFU}$, respectively, meanwhile, formula 4 was 97, 132, 182 and $210 \times 10^{3}$ CFU, respectively. The relatively high initial counts of control samples may be attributed to the minced process, which introducing the pathogens into the interior of the meat and contributes to the increase of total viable counts of the products (Mead and Griffin, 1998).

Table (7): Total bacteria count of beef burger formulae during storage period.

\begin{tabular}{|l|c|c|c|c|}
\hline Formulae & $\begin{array}{c}\text { Zero time } \\
\times 10^{3}\end{array}$ & $\begin{array}{c}\text { After one month } \\
\times 10^{3}\end{array}$ & $\begin{array}{c}\text { After two } \\
\text { months } \times 10^{3}\end{array}$ & $\begin{array}{c}\text { After three } \\
\text { months } \times 10^{3}\end{array}$ \\
\hline Control & 99 & 141 & 213 & 305 \\
\hline Formula 1 & 94 & 102 & 120 & 150 \\
\hline Formula 2 & 97 & 109 & 127 & 167 \\
\hline Formula 3 & 96 & 108 & 125 & 161 \\
\hline Formula 4 & 97 & 132 & 182 & 210 \\
\hline
\end{tabular}

\section{CONCLUSION}

Meat is still regarded as valuable protein source food in the world. However, consumer's preference on healthy meat product is also increasing due to various chronic diseases like cardio vascular diseases, cancer and diabetics. Reducing or replacing saturated animal fat could be the solution for producing nutritious product but there are challenges for preparing a healthy product and maintaining its sensory quality for the consumers. There are so many types of technological advancement that have been developed to reduce or replace the animal fat, for example, incorporating lemongrass and red sorghum bran as alternative sheep fat and natural antioxidant to improving oxidative stability during storage period in the formulae. Incorporation of lemongrass and red sorghum bran could be health beneficial, but, it may be negatively affect the overall quality of the product. Therefore, the research is necessary to produce healthy and tasteful meat products.

\section{REFERENCES}

Abubakar, M.C.; Ukwuani, A.N. and Shehu, R.A. (2008). Phytochemical screening and antibacterial activity of Tamarindus indica pulp extract. Asia J. Biochem., 3(2): 134-138.

Ahmed, J.; Shivhare, U.S. and Raghavan. G.S.V. (2004). Thermal 


\section{Gehan I. Abd El-Wahab}

degradation kinetics of anthocyanin and visual colour of plum puree. Eur. Food Res. Technol., 218:525528.

Altabari, G., 2009. Meat hygiene and safety. AL-Ahsa Municipality, pp: 311.

American Public Health Association. (1992). Standard Methods for the Examination of Dairy Products. American Pub1. Health Assoc. Inc. $16^{\text {th }}$ Ed., Washington D.C.

AMSA, (1995). Research Guidelines for Cookery, Sensory Evaluation and Instrumental Tenderness Measurements of Fresh Beef. American Meat Science Assoc., Chicago, U.S.A.

Anagnostopoulou, A.; Maria, K.P.; Papageorgiou, P.V.; Assimopoulou, N.A. and Boskou, D. (2006). Radical scavenging activity of various extracts and fractions of sweet orange peel (Citrus sinensis). Food Chem., 94 : 19-25.

AOAC (2005). Official Methods of Analysis of the Association of Official Analytical Chemists, $18^{\text {th }}$ ed., Washington, D.C.

Asaolu, M.F.; Oyeyemi, O.A. and Olanlokun, J.O. (2009).Chemical compositions, phytochemical constituents and in vitro biological activity of various extracts of Cymbopogon citrates. Pakistan J. Nutr., 8 (12):1920-1922.

Awika, J.M.; Dykes, L.; Gu, L.; Rooney, L.W. and Prior, R.L. (2003a). Processing of sorghum and sorghum products alters procyanidin oligomer and polymer distribution and content. J. Agric. Food Chem., 51:5516-5521.

Awika, J.M.; Rooney, L.W., Wu, X., Prior, R.L. and Cisneros- Zevallos, L. (2003b). Screening methods to measure antioxidant activity of sorghum (Sorghum bicolor) and sorghum products. J. Agric. Food Chem., 51: 6657-6662.

Awika, J. M., and L. W. Rooney. 2004. Sorghum phytochemicals and their potential impact on human health. Phytochem., 65:1199-1221.

Awika, J.M., Rooney L.W. and Waniska, R.D. (2004). Properties of 3deoxyanthocyanins from sorghum. J. Agric. Food Chem., 52: 43884394.

Awika, J.M.; McDonough, C.M. and Rooney, L.W. (2005). Decorticating sorghum to concentrate healthy phytochemicals. J. Agric. Food Chem., 53(16): 6230-6234.

Beta, T.; Rooney, L.W.; Marovatsanga, L.T. and Taylor, J.R.N. (2000). Effect of chemical treatments on polyphenols in malt quality and sorghum. J. Cereal Sci., 31: 295302.

Bourne, M. C. (2003). Food texture and viscosity: Concept and measurement. Elsevier Press, New York/ London.

Chambers, E.N. and Bowers, J.R. (1993). Consumer perception of sensory quality in muscle foods. Food Technol., 47(11):116-120.

Chang, C.; Yang, M. H. ; Wen, H. M. and Chern, J.C. (2002). Estimation of total flavonoid content in propolis by two complementary colometric methods. J. Food Drug Analysis, 10(3): 178-182.

Dykes, L. and Rooney, L.W.(2007). Phenolic compounds in cereal grains and their health benefits. Cereal Foods World, 52(3):105111.

Edeoga, H.O.; Okwu, D.E. and Mbaebie, B.O. (2005). Phytochemical constituents of some Nigeria medicinal plants. Afr. J. Biotech., 4(7): 685-688.

Elleuch, M.; Bedigian, D.; Roiseux, O.; Besbes, S.; Blecker, C. and Attia, H. (2011). Dietary fiber and fiber- 


\section{Utilization from lemongrass and red sorghum bran as natural antioxidant and alternative for fat to improving quality and oxidative stability of beef burger}

rich by-products of food processing: Characterization, technological functionality and commercial applications: A review. J. Food Chem., 124: 411-421.

Figueirinha, A.; Paranhas, A.; PenezAlonso, J.J.; Santos, C.B. and Betisa, M.T. (2008). Cymbopogon, citratus leaves; Characterization of flavonoids by HPLC-PDA-ESI/MS and an approach to their potential as a source of bioactive polyphenols. Food Chem., 110: 718-728.

Fuleki, T. and Francis, F.J. (1968). Determination of total anthocyanin and degradation index for craneberry juice. Food Sci., 33: 78-83.

Hemphill, S.P. (2006). Effect of sorghum bran addition on lipid oxidation and sensory properties of ground beef patties differing in fat levels. M.S. Thesis, Texas A\&M University, College Station, TX.

Jenschke, B. E. (2004). Chemical, color and sensory attributes of sorghum bran enhanced beef patties in a high oxygen environment. M.S. thesis, Texas A\&M University, College Station, TX.

Joseph, M. A. ; Lloyd, W.R. and Ralph, D.W. (2004). Anthocaynins from black sorghum and their antioxidant properties. Food Chem., 90: 293-301.

Judge, M.D.; Aberle, E.D.; Forest, J.C.; Hedrick, M.B. and Merkel, R.A. (1990). Principle of meat science, Kendall Hunt Publishing Company, Dubuque, Iowa, USA.

Kumar, J.K. and Sinha, A.K. (2004). Resurgence of natural colorants: A holistic view. Natr. Pro. Lett. 18:59-84.

Kumar, P.; Sunil, K.; Tripathi, M.K.; Nikhil, M.; Rajeev, R.; Bhat, Z. F. and Pramod, K. Singh (2013). Flavonoids in the development of functional meat products: A review, Vet. World 6(8) : 573-578.

Lawless, H.T. and Heymann, H. (2010). Introduction, Scaling, Descriptive Analysis. Sensory evaluation of food: Principles and Practices. $2^{\text {nd }}$ ed., New York, Springer, 1-2; 5-8; 149-150; 154-156; 227-228; 234.

Lopez, I.L.; Cofrades, S. and Colmenero, F.J. (2009). Low fat frankfurters enriched with n-3 PUFA and edible seaweed. Meat Sci., 83:148-154.

Martin, F.R.; Frutos, M. J.; Pérez Alvarez, J. A.; Martinez - Sánchez, F. and Tel Rio, J.A. (2002). Flavonoids as

neutraceutical: Structural related antioxidant properties and their role on ascorbic acid preservation. In: Atta Ur-Rahman (Ed.), Studies in natural products chemistry, 26: 324-389.

Mead, P.S. and Griffin, P.G. (1998). Escherichia coli O157:H7. The Lancet vol. 352, October 10.

Meda, A.; Lamien, C.E.; Romito, M.; Millogo, J. and Nacoulma, O.G. (2005). Determination of the total phenolic, flavonoid and proline contents in Burkina Fasan honey, as well as their radical scavenging activity. Food Chem., 91(3): 571577.

Mehraban, F.; Nasim, O.T. and Fereshteh, J. (2005). Anti-dermatophyte activities of Eucalytus camaldulensis in comparism with Griseofulvin. Iran. J.S. Pharmacol. Therapeut., 4: 80-83.

Melo, S.F.; Soares, S.F.; Coasta, R.F.; Silva, C.R.; Oliveira, M.B.N.; Bezerra, R.J.A. ; CaldeiradeAraujo, A. and Bernardo-Fillo, M. (2001). Effect of the Cymbopogon citratus, Maytenus ulicifola and Baccharis genis telloides extract against the stannous chloride oxidative damage in Escharichia coli. Mutat. Res., 496: 33-38. 


\section{Gehan I. Abd El-Wahab}

Mensah, P.; Yeboah-Manu, D.; OwusuDarku, K. and Ablordey, A. (2002). Street Food in Accra, Ghana: how safe are they?. Bull. WHO, 80: 546-556.

Morr, M.L. (1970). Introductory Food, Laboratory Manual of Food Preparation and Evaluation. $2^{\text {nd }}$ Ed. Mac Millan Pub. Co. Inc., New York, Coclier Mac Millan Pub., London.

Morrissey, P.A.; Buckley, D.J.; Sheehy, P.J.A. and Monahan, F.J. (1994). Vitamin $\mathrm{E}$ and meat quality. Proceed. Nutrit. Soc., 53: 289-295.

Raharjo, S. and Sofos, J. N. (1993). Methodology for measuring malonaldhyde as a product of lipid peroxidation in muscle tissues. $\mathrm{J}$. Meat Sci., 35: 145- 169.

SAS (2004). Statistical Analysis System. SAS User's Statistics SAS Institute Inc. Editors, Cary, NC.

Schmedes, A. and G. Holmer, 1989. A new thiobarbituric acid (TBA) method for determination of free malonaldehyde (MDA) and hydroperexides selectivity as a measure of lipid peroxidation. American J. Oil Chem. Soc., 66: 813-7.
Soloviev,V. E., (1966). Meat Aging. Food Industry. Pub., Moscow, PP: 5381.

Solomakos, N.; Govaris, A.; Koidis, P. and Botsoglou, N. (2008). The antimicrobial effect of thyme essential oil, nisin, and their combination against Listeria monocytogenes in minced beef during refrigerated storage. $\mathrm{J}$. Food Microbiol., 25 (1): 120- 127.

Yassin, N.M. N. (2003). Effect of Storage Conditions on the quality parameters of differently treated fish. Ph. D. Thesis, Fac. Agric. Ain Shams, Univ. Cairo. Egypt.

Waniska, R.D. (2000). Structure, phenolic compounds and antifungal proteins of Sorghum caryopses. In: A. Chandrashekar, R. Bandyopadhyay \& A.J. Hall (Eds.), Technical and Institutional Options for Sorghum Grain Mold Management: Proceedings of An International Consultation (pp. 72-106). ICRISAT. 
الاستفادة من حشيشة الليمون وقشور الذرة الحمراء كمضادات للأكسدة الطبيعية وبديل للاهون لتحسين الجودة والثبات التاكسدي لبرجر اللحم البقري الأدمادي

\author{
جيهان أبراهيم عبد الوهاب \\ قسم الأقتصاد المنزلى ـ كلية التربية النو عية- جامعة عين شمس - مصر
}

أجريت هذه الدراسة لتقييم برجر اللحم المعد من حشيشة الليمون وقشتور السورجم الأحمر كمضاد للأكسدة

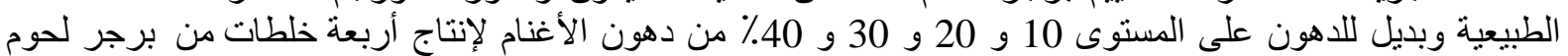

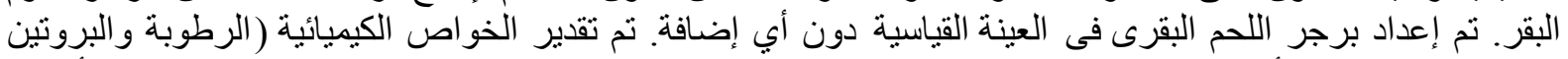

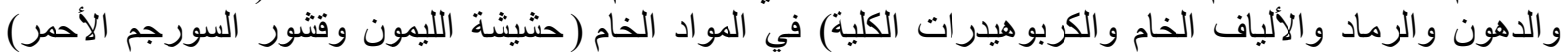

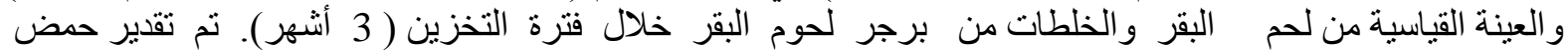
الثيو باربيتوريك ، سعة الاحتفاظ بالماء ، الفقد اثناء الطهي ، الانكماش ، وتحليل النسيج (TPA) و العدد الكلي للبكتريا في

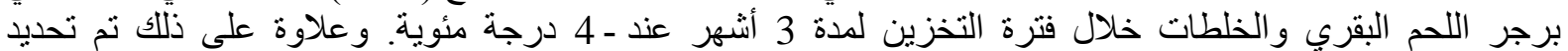

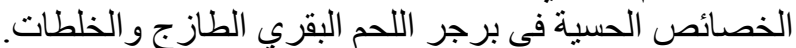

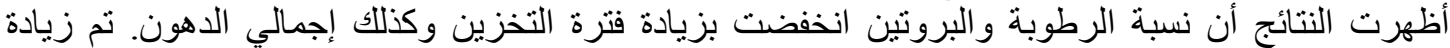

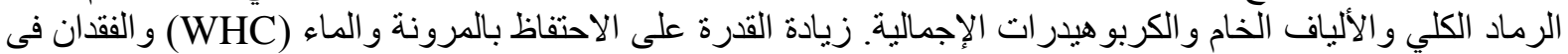

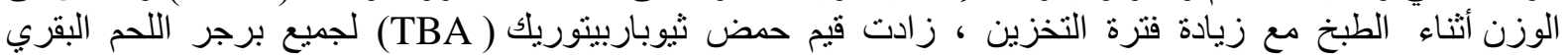

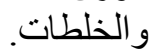

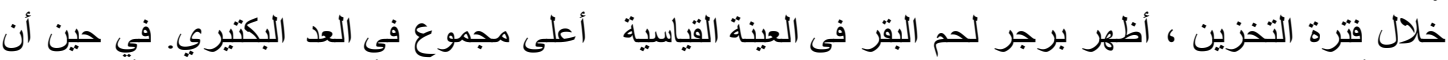

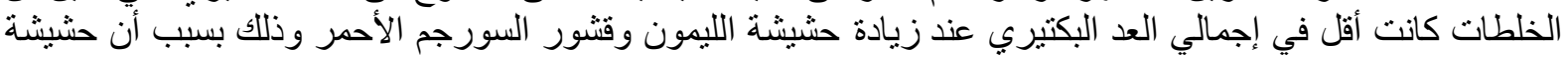

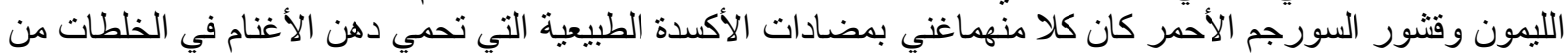

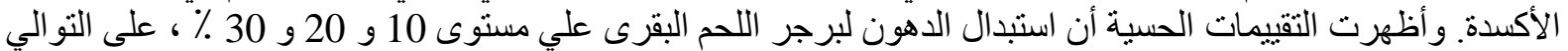

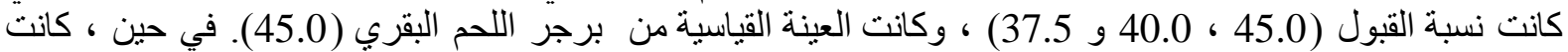

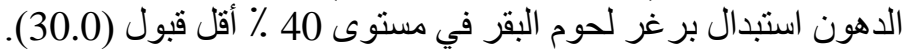

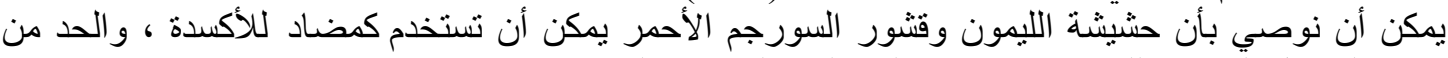
أكسدة الدهون و العو امل المضادة للبكتيريا في برجر لـمن البرن البر المبرد وخلطاتها. 